\title{
Introduction of the Hungarian Detailed Soil Hydrophysical Database (MARTHA) and its use to test external pedotransfer functions
}

\author{
${ }^{1}$ A. MAKÓ, ${ }^{1}$ B. TÓTH, ${ }^{1}$ H. HERNÁDI,${ }^{2,3}$ CS. FARKAS and ${ }^{4}$ P. MARTH \\ ${ }^{1}$ Department of Plant Production and Soil Science, Georgikon Faculty, University of \\ Pannonia, Keszthely, ${ }^{2}$ Research Institute for Soil Science and Agricultural Chemistry \\ (RISSAC) of the Hungarian Academy of Sciences, Budapest, ${ }^{3}$ Bioforsk, Norwegian \\ Institute for Agricultural and Environmental Research, Ås (Norway) and ${ }^{4}$ Central Plant \\ and Soil Protection Service, Budapest
}

The lack of sufficient data of soil hydraulic properties often limits the application of different simulation models (e.g. those calculating crop growth, nutrients and pollutants dynamics, $\mathrm{CO}_{2}$ sequestration, soil organic matter dynamics). Current methods for direct measurements of soil hydraulic properties are complex, timeconsuming and costly. Consequently, there has long been interest in methods for estimating soil hydrological parameters from commonly available (more easily or routinely measured) soil parameters, such as particle-size distribution, bulk density and organic matter content (e.g. COSBY et al., 1984; AHUJA et al., 1985; RAJKAI, 1988; VEREECKEN et al., 1989, VAN GENUCHTEN \& LEIJ, 1992; RAJKAI et al., 2004). Additional laboratory soil parameters are rarely used (WÖSTEN et al., 2001). Approaches used for generating soil information from existing soil parameters are called pedotransfer functions (PTFs). The term was introduced by BOUMA \& VAN LANEN (1987), and became of common use after BOUMA (1989).

In addition to easily measured soil properties other information, as field topographic parameters (PACHEPSKY et al., 2001; RAWLS \& PACHEPSKY, 2002) and the combination of physical data and terrain attributes (ROMANO \& PALLADINO, 2002), were also used to predict soil hydraulic properties. ANDERSON and BOUMA (1973) and BoumA et al. (1979) predicted saturated hydraulic conductivity $\left(\mathrm{K}_{\text {sat }}\right)$ values from morphometric soil data. MCKEAGUE et al. (1982) related measured $K_{\text {sat }}$ values to soil structure, porosity, biopores, soil texture, consistency and density. They used their results for creating $\mathrm{K}_{\text {sat }}$ classes for soil horizons. BOUMA (1989) or CRESSWELL et al. (1999) used functional morphologic descriptors (e.g. areal porosity, structure grade and field estimated aggregate stability) to describe the morphological characteristics of soils, because it is difficult to analyse conventional morphological data (used for soil classification and mapping) statistically. The taxonomical classes (soil type or subtype) can also integrate a lot of unknown or less

Correspondence to: ANDRÁS MAKÓ, Department of Plant Production and Soil Science, Georgikon Faculty, University of Pannonia, H-8360 Keszthely, 16 Deák F. Str., Hungary. Email:mako@georgikon.hu 
known physical, chemical, mineralogical and morphological properties of soils (TÓTH et al., 2008). In the case of brown forest soils the soil water retention characteristics were efficiently estimated using the relating grouped mean data and the soil subtype, texture and humus data codes of the soil maps (MAKÓ et al., 2005). TóTH et al. (2006) sufficiently predicted the water retention and the hydraulic conductivity values at a selected case-study area according to the category-type data of the soil maps.

Recently a large number of estimation procedures have been developed, using different methods, based on multiple linear regression (e.g. GUPTA \& LARSON, 1979; VEREECKEN et al., 1989; WÖSTEN et al, 1999; RAJKAI et al., 1999), on physical-empirical approaches (e.g. ARYA \& PARIS, 1981), on neural networks (e.g. PACHEPSKY et al., 1995; SCHAAP et al, 1998; MINASNY \& MCBRATNEY, 2002), or on classification and regression trees (CART) (PACHEPSKY et al., 2006).

The availability of a thoroughly checked hydrophysical soil database is a prerequisite for using the above-mentioned different data mining tools and for developing pedotransfer functions. A number of hydrophysical soil databases have been constructed in the last two decades worldwide. UNSODA (Unsaturated Soil Hydraulic Database) is an international database of unsaturated soil hydraulic properties, including information on water retention, hydraulic conductivity, soil water diffusivity and basic soil properties. It contains approximately 800 data sets (LEIJ et al., 1996). The HYPRES (Hydraulic Properties of European Soils) database - developed by 20 institutions from 12 European countries (WÖSTEN et al., 1999) contains measured soil hydraulic characteristics for 5521 soil horizons. The International Soil Reference and Information Centre (ISRIC) prepared a uniform soil data set for the development of pedotransfer functions. The necessary chemical and physical soil data have been derived from ISRIC's Soil Information System (ISIS) and the CD-ROM of the Natural Resources Conservation Service (USDA-NRCS). The name of this data set is IGBT-DIS soil database and contains data for 131,472 samples, originating from 20,920 profiles (TEMPEL et al, 1996). HODNETT and TOMASELLA (2002) selected data from the IGBT-DIS soil database, which originated from tropical regions (771 horizons from 21 tropical countries) to develop pedotransfer functions for tropical soils. Using the Swedish soil physical database (2025 soil layers, about 300 soil profiles) a three-parameter van Genuchten-type model was constructed by RAJKAI et al. (1996) to describe the water retention characteristic data of Swedish soils. KÄTTERER et al. (2005) developed pedotransfer functions to estimate plant available water and bulk density from a database of arable soils in Sweden.

In Hungary two databases are available for developing site-specific or national pedotransfer functions. One of these is the dataset of the Research Institute for Soil Science and Agricultural Chemistry of the Hungarian Academy of Science (RISSAC), which contains information about 270 soil samples, mainly from the Great Hungarian Plain. The pedotransfer functions developed on this dataset (e.g. RAJKAI, 1988, RAJKAI et al., 1999) can successfully be applied for Hungarian chernozem soils. The other hydrophysical dataset is the Unsaturated Soil Hydraulic Database of Hungary (HUNSODA), including data of about 840 soil samples and 
soil water retention characteristics of 576 soil horizons (NEMES, 2002). Both of these databases are very useful, their disadvantage, however, is that they only provide information about narrow groups of arable soils.

In the framework of Grant No. T048302 provided by the National Scientific Research Fund (OTKA) we had the opportunity to develop the Hungarian Detailed Soil Hydrophysical Database (MARTHA) with the collaboration of the County Offices of the Hungarian Plant and Soil Protection Service.

The objective of the presented work was to introduce the newly developed Hungarian MARTHA database (ver2.0), then to test two common pedotransfer functions on the database and to evaluate the accuracy of the predictions.

\section{Materials and Methods}

\section{The description of MARTHA ver2.0 database}

Our aim was to collect all of the measured soil hydrophysical data available in Hungary and to harmonize them into a uniform database, called MARTHA (acronym of the Hungarian name of the database), which is the Hungarian Detailed Soil Hydrophysical Database. As data on agricultural areas were received from all over the country, this database is representative for Hungarian soils being under cultivation. It was applied on a database server of SQL platform (Firebird 2.0). The selected program language was Delphi. To visualize the locations of the soil profiles GoogleMap connection was used. The recent version is the MARTHA ver 2.0.

The MARTHA ver2.0 database includes the existing smaller datasets: the above-mentioned dataset of HUNSODA (750 horizons) and the data of the Hungarian Soil Information and Monitoring System (TIM) (4647 horizons) (VÁRALLYAY et al., 2009). Further to these basic datasets, the second main additional data source is that from the Plant and Soil Protection Services of the Hungarian Counties, which produce various purpose soil assessments (e.g. for irrigation planning) and collect data for these needs (9608 horizons). The first period of data collection has closed. The MARTHA ver 2.0 database currently contains the soil physical, chemical data of 15,005 soil horizons belonging to 3,937 soil profiles. Fig. 1 outlines the location of the MARTHA's soil profiles on the topographical map of Hungary.

The language of the program is Hungarian; the English version will be available soon. The management software is executed with the help of menus. The user can select the proper soil sample according to the identifiers of the soil profiles and the number of their horizons. The general, chemical and physical parameters of the soil profiles can be reached from the overlapping sheets. The General parameters sheet contains basic information about the soil profile (identifier; origin of the sample; name of the county where the soil profile is located; EOV coordinates; GPS coordinates; soil type and subtype); the selected soil profile's picture and location on the map (with Google Map connection); horizons of the selected soil profile (name and depth of the horizon). The Chemical parameters sheet stores data about the $\mathrm{pH}\left(\mathrm{H}_{2} \mathrm{O}\right)$; $\mathrm{pH}(\mathrm{KCl})$; acidity values $\left(\mathrm{y}_{1}, \mathrm{y}_{2}\right)$; calcium carbonate; salt content; exchangeable $\mathrm{Na}$; sum of $\mathrm{Na}, \mathrm{K}, \mathrm{Ca}, \mathrm{Mg}$ cations; CEC and organic matter content. 


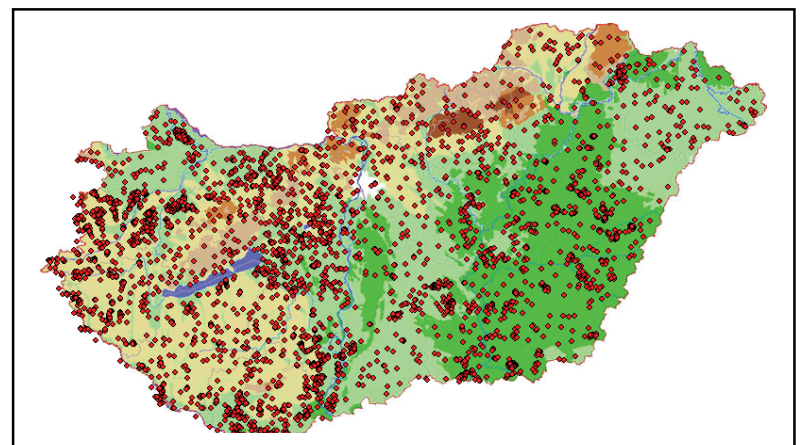

Fig. 1

Locations of soil profiles in the MARTHA ver2.0 database (visualized by the software)

The Physical parameters sheet holds the following parameters: soil water retention characteristics (soil water contents at water potentials of -1, -2.5, -10.0, -32.6, $-100,-200,-316,-2512,-15850$ and $-1584893 \mathrm{hPa})$; particle size distribution (0.25-2;0.05-0.25; 0.02-0.05; 0.01-0.02; 0.005-0.01;0.002-0.005; <0.002 mm); bulk density; specific density; plasticity limit (according to Arany); hygroscopic water content; hydraulic conductivity. Soil properties were measured in accordance with the Hungarian standards (BUZÁs, 1993). Table 1 shows the absolute and relative availability of all sample attributes in the database.

\section{Testing pedotransfer functions}

One of the potential applications of MARTHA ver2.0 is to develop and apply methods for estimating water retention characteristics from more easily measured data. To establish this work the reliability of two conventional pedotransfer functions (PTFs) was studied.

The Hungarian widely used point estimation PTFs (RAJKAI, 1988; RAJKAI \& VÁRALLYAY, 1989) were tested first. Secondly the continuous PTFs of WÖSTEN et al. (1999), developed on the HYPRES European database, were applied.

As all soil parameters selected for the two prediction methods were not necessarily measured for all soil samples (Table 1), there were a number of gaps in the MARTHA ver2.0 database. Therefore the database was checked and reduced to 7524 horizons. This condensed database was used in the further statistical examination.

The quality of the estimated retention values was evaluated using the determination coefficient, $R^{2}$ coefficient (for correlation between the measured and the estimated soil water contents at several $\mathrm{pF}$ values) and RMSR (Root mean squared residual) (NEMES et al., 2003). Following RAJKAI et al. (2004), the goodness of the predicted water retention was also evaluated. The prediction was considered 'good' if the RMSR was less than $2.5 \%$. The estimation efficiency (EE) of the different estimation procedures was defined as the percentage of 'good' predicted soils. 
Table 1

Characterization of the MARTHA ver2.0 database

\begin{tabular}{|c|c|c|}
\hline Attribute & Count & $\%$ \\
\hline CLASS HUN (soil classification - HUN - national) & 14748 & 98.3 \\
\hline CLASS_WRB (soil classification - WRB) & 14748 & 98.3 \\
\hline CLASS_SOILTAX (soil classification - Soil Taxonomy) & 14748 & 98.3 \\
\hline HOR_N (horizon number) & 15005 & 100.0 \\
\hline HOR_DES (horizon designation) & 14995 & 99.9 \\
\hline TOP_D (depth of the top of the sample, $\mathrm{cm}$ ) & 14948 & 99.6 \\
\hline BOT_D (depth of the bottom of the sample, cm) & 14897 & 99.3 \\
\hline OM (weight $\%$ of organic matter - Tyurin method) & 13388 & 89.2 \\
\hline CAR (weight $\%$ of free $\mathrm{CaCO}_{3}$ ) & 11455 & 76.3 \\
\hline KA (plasticity limit according to Arany) & 14696 & 97.9 \\
\hline PH_H2O (pH in a 1:2.5 soil-water suspension) & 14770 & 98.4 \\
\hline $\mathrm{PH}_{-}^{-} \mathrm{KCL}$ (pH in a 1:2.5 soil-KCl suspension) & 7542 & 50.3 \\
\hline Y1 $\left(\mathrm{Na}_{4} \mathrm{OAc}\right.$. extractable acidity, in cmol(+) $\left.\mathrm{kg}^{-1}\right)$ & 3151 & 21.0 \\
\hline Y2 ( $\mathrm{KCl}$ extractable acidity, in $\left.\mathrm{cmol}(+) \mathrm{kg}^{-1}\right)$ & 979 & 6.5 \\
\hline SALT (weight $\%$ of total salt content) & 11898 & 79.3 \\
\hline CSNA (exchangeable $\mathrm{Na}$, in $\mathrm{cmol}(+) \mathrm{kg}^{-1}$ ) & 5712 & 38.1 \\
\hline CEC (cation exchange capacity of the soil, in cmol $(+) \mathrm{kg}^{-1}$ ) & 10313 & 68.7 \\
\hline $\mathrm{S}$ (sum of $\mathrm{Na}, \mathrm{K}, \mathrm{Ca}, \mathrm{Mg}$ cations, in cmol $(+) \mathrm{kg}^{-1}$ ) & 330 & 2.2 \\
\hline CLAY_USDA_HUN (weight $\%$ of particles $<0.002 \mathrm{~mm}$ ) & 14311 & 95.4 \\
\hline SILT_ÜSDA (weight $\%$ of particles $0.05-0.002 \mathrm{~mm}$ ) & 14322 & 95.4 \\
\hline SAND USDA (weight $\%$ of particles $2.0-0.05 \mathrm{~mm}$ ) & 14311 & 95.4 \\
\hline SILT_HUN (weight $\%$ of particles $0.02-0.002 \mathrm{~mm}$ ) & 14313 & 95.4 \\
\hline SAND_HUN (weight $\%$ of particles $2.0-0.02 \mathrm{~mm}$ ) & 14310 & 95.4 \\
\hline FINE_SILT_1 (weight $\%$ of particles $0.005-0.002 \mathrm{~mm}$ ) & 14313 & 95.4 \\
\hline FINE_SILT_2 (weight $\%$ of particles $0.01-0.005 \mathrm{~mm})$ & 14313 & 95.4 \\
\hline FINE_SILT_3 (weight $\%$ of particles $0.02-0.01 \mathrm{~mm}$ ) & 14313 & 95.4 \\
\hline COARSE_SILT (weight $\%$ of particles $0.05-0.02 \mathrm{~mm}$ ) & 14313 & 95.4 \\
\hline FINE_SAND (weight $\%$ of particles $0.25-0.1 \mathrm{~mm}$ ) & 14064 & 93.7 \\
\hline COARSE_SAND (weight $\%$ of particles $1.0-0.5 \mathrm{~mm}$ ) & 14064 & 93.7 \\
\hline HY1 (hygroscopic water content (weight\%)) & 5061 & 33.7 \\
\hline BD (bulk density - oven dry at $105^{\circ} \mathrm{C}-$ in $\mathrm{kg} \cdot \mathrm{dm}^{-3}$ ) & 12629 & 84.2 \\
\hline DENS (density, in $\mathrm{t} \cdot \mathrm{m}^{-3}$ ) & 440 & 2.9 \\
\hline PF_0 (moisture content at $-1 \mathrm{hPa}=\mathrm{pF} 0(\mathrm{vol} \%))$ & 12739 & 84.9 \\
\hline $\mathrm{PF}^{-} 04($ moisture content at $-2.5 \mathrm{hPa}=\mathrm{pF} 0.4(\mathrm{vol} \%))$ & 999 & 6.7 \\
\hline PF_1 (moisture content at $-10 \mathrm{hPa}=\mathrm{pF} 1.0($ vol\%) $)$ & 1849 & 12.3 \\
\hline $\mathrm{PF}_{-} 15($ moisture content at $-32.6 \mathrm{hPa}=\mathrm{pF} 1.5(\mathrm{vol} \%))$ & 4036 & 26.9 \\
\hline PF_2 (moisture content at $-100 \mathrm{hPa}=\mathrm{pF} 2.0($ vol\%) $)$ & 7870 & 52.4 \\
\hline PF_23 (moisture content at $-200 \mathrm{hPa}=\mathrm{pF} 2.3(\mathrm{vol} \%))$ & 889 & 5.9 \\
\hline PF_25 (moisture content at $-316 \mathrm{hPa}=\mathrm{pF} 2.5(\mathrm{vol} \%))$ & 12663 & 84.4 \\
\hline PF_34 (moisture content at $-2512 \mathrm{hPa}=\mathrm{pF} 3.4(\mathrm{vol} \%))$ & 1753 & 11.7 \\
\hline PF_42 (moisture content at $-15850 \mathrm{hPa}=\mathrm{pF} 4.2(\mathrm{vol} \%))$ & 12759 & 85.0 \\
\hline $\mathrm{PF}^{-} 62$ (hygroscopic water content $\left.(\mathrm{vol} \%)\right)(-1584893 \mathrm{hPa}=\mathrm{pF} 6.2)$ & 12483 & 83.2 \\
\hline K SAT (saturated hydraulic conductivity $-\mathrm{cm} \cdot \mathrm{day}^{-1}$ ) & 2879 & 19.2 \\
\hline
\end{tabular}


Optimum partitioning of databases with classification trees (SPSS TREES CHAID) was used to find the best grouping of samples according to the RMSR values (SPSS, 2001). It was assumed that water retention is also affected by soil structure and therefore the quality of estimation procedures depends on the soil structural groups. Because of the lack of direct soil structural data in the MARTHA ver2.0 database, the empirical knowledge about the different soil classification categories (soil types and subtypes) was used to predict the characteristic structural parameters of the soils. For this purpose, the grade of structure and the shape of aggregates were described. Four classes were used to characterize the grade: 1. structureless, where no observable aggregation occurs, 2. poorly structured, when the aggregates are slightly observable, 3. medium structured, when aggregates are well formed in the undisturbed soil, but the stability of the aggregates is moderate, 4. well structured, when aggregates are distinct in the undisturbed soil and, the stability of the aggregates is high. The shape of aggregates was classified into five classes: 1. not aggregated, 2. granular, 3. prismatic, 4. blocky, and 5. columnar. These structural parameters were used as grouping variables to define the soil groups with distinctly different RMSR values.

\section{Results and Discussion}

The statistical evaluation of the two estimation procedures is given in Table 2. In general, the application of both examined pedotransfer functions (RAJKAI, 1988; WÖSTEN et al., 1999) was not very successful. This is presumably due to the fact that the data set used by Rajkai originated mainly from the Great Hungarian Plain. Thus, it represented only a few Hungarian soil types. On the other hand, the HYPRESS database used by WÖSTEN et al. (1999) came from different European countries, where soil forming conditions may differ significantly from the Hungarian circumstances. These results suggest that it is necessary to develop new PTFs on the basis of the new Hungarian database, which would be representative for a wider range of the Hungarian soils.

In the second part of our analysis the effect of structural differences on the goodness of estimation was examined. The RMSR values calculated for the classi-

Table 2

Goodness of estimation indicators ( $\mathrm{R}^{2}$; RMSR; EE) for different types of PTFs

\begin{tabular}{|c|c|c|c|c|c|}
\hline \multirow{2}{*}{$\begin{array}{c}\text { Estimation } \\
\text { procedure }\end{array}$} & \multicolumn{3}{|c|}{$\mathrm{R}^{2}$ coefficient } & \multirow{2}{*}{$\begin{array}{c}\text { RMSR } \\
\text { (vol } \%)\end{array}$} & $\begin{array}{c}\text { EE } \\
(\%)\end{array}$ \\
\cline { 2 - 4 } & $\mathrm{pF} \mathrm{0}$ & $\mathrm{pF} 2.5$ & $\mathrm{pF} \mathrm{4.2}$ & \\
\hline $\begin{array}{c}\text { Measured vs. RAJKAI } \\
\text { (1988) }\end{array}$ & 0.68 & 0.53 & 0.54 & 4.715 & 16.6 \\
$\begin{array}{c}\text { Measured vs. } \\
\text { WÖSTEN et al. (1999) }\end{array}$ & 0.66 & 0.53 & 0.54 & 5.182 & 9.1 \\
\hline
\end{tabular}

Remark: $\mathrm{R}^{2}$ = determination coefficient; $\mathrm{RMSR}$ = root mean squared residual; $\mathrm{EE}$ = estimation efficiency 
fication trees using the two different pedotransfer functions are shown in Fig. 2. The grade of aggregation was the best grouping parameter in both cases. A stronger grade decreased the RMSR values (increased the goodness of estimation). Based on the observed effect of the aggregate's grade on the estimation, it can be supposed that the databases, which were used for developing the PTFs contained less structureless soils than the MARTHA ver2.0 database did. The shape class was in the list
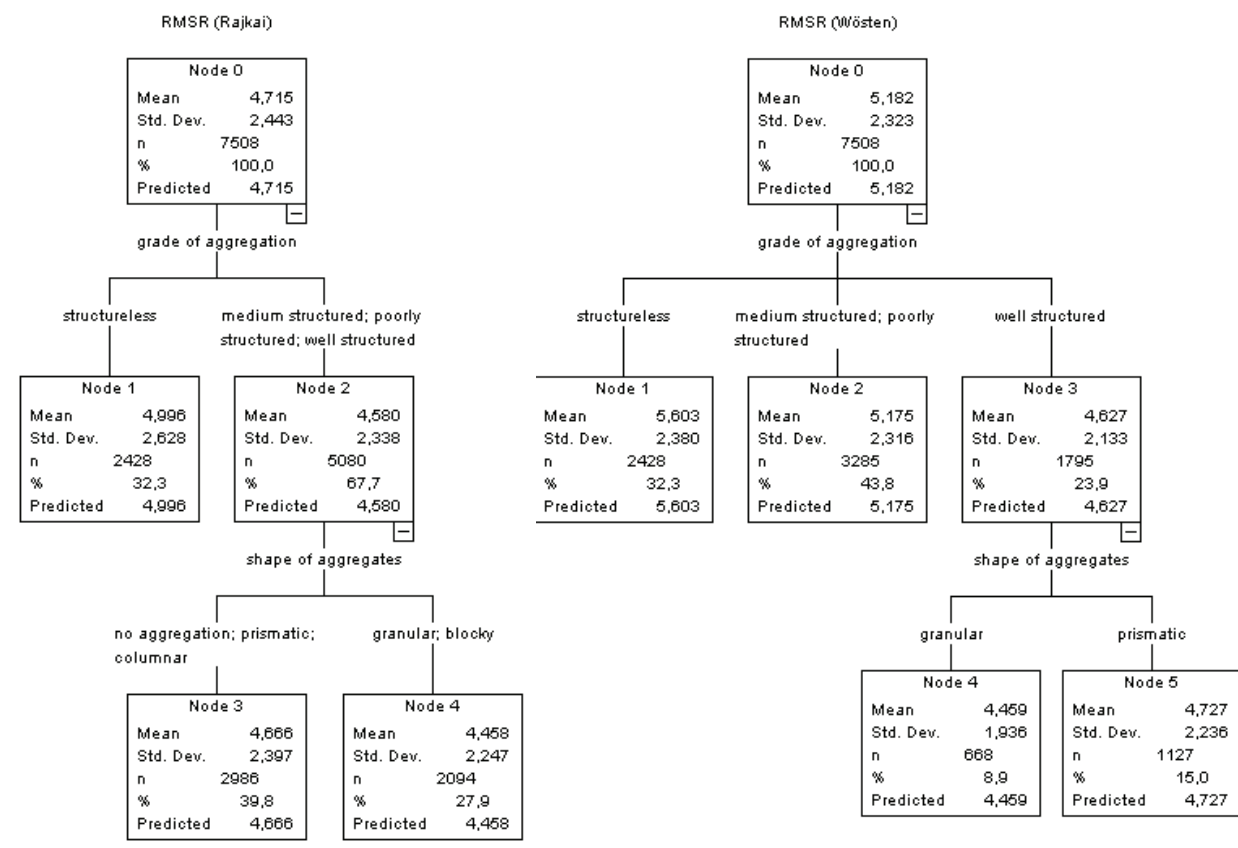

Fig. 2

Classification trees to group soil samples according to root mean squared residual (RMSR) values $($ vol $\%)$

of grouping parameters only in the case of structured soil samples (Rajkai's PTFs) or in well-structured soil samples (Wösten's prediction). A slight decrease in RMSR values (increase in goodness of estimation) was observed for groups with granular structure. Our hypothesis is that the data sets of both prediction methods represented more soils with granular structure than others. Another reason of this experience may be that salt content, sodium saturation or clay mineral composition cause less estimation errors in the case of soils with granular structure than in soils with e.g. columnar or prismatic structure. Results of the classification tree method show that defining and quantifying the soil structure may partly explain the inaccuracy of soil water retention prediction. Furthermore, the structural data may serve as grouping variable for the further development of class PTFs. As soil forming conditions (represented in the MARTHA database by soil classification units) in Hungary differ to a great extent, structural soil characteristics are greatly variable. Our results 
indicate that soil structural properties could serve as important additional information in PTF development, even in the case of their indirect incorporation.

\section{Summary}

The Hungarian Detailed Soil Hydrophysical Database, called MARTHA ver2.0 has been developed to collect information on measured soil hydraulic and physical characteristics in Hungary. Recently this is the largest detailed national hydrophysical database, containing controlled information from a total of 15,005 soil horizons.

Two commonly used pedotransfer functions were tested to evaluate the accuracy of the predictions on the MARTHA data set, representative for Hungarian soils. In general, the application of both examined pedotransfer functions (RAJKAI, 1988; WÖSTEN et al., 1999) was not very successful, because these PTFs are representative for other soil groups. The classification tree method was used to evaluate the effect of soil structure on the goodness of estimations. It was found that using the soil structure data the inaccuracies of soil water retention predictions are more explainable and the structure may serve as a grouping variable for the development of class PTFs.

Key words: soil hydrophysical database, pedotransfer functions, water retention

\section{References}

Ahuja, L. R., NANEY, J. W. \& Williams, R. D., 1985. Estimating soil water characteristics from simpler properties or limited data. Soil Sci. Soc. Am. J. 49. 1100-1105.

ANDERSON, J. L. \& BoumA, J., 1973. Relationships between saturated hydraulic conductivity and morphometric data of an argillic horizon. Soil Sci. Soc. Amer. Proc. 37. 408-413.

ARYA, L. M. \& PARIS, J. F., 1981. A physicoempirical model to predict soil moisture characteristics from particle-size distribution and bulk density data. Soil Sci. Soc. Am. J. 45. 1023-1030.

BoumA, J., 1989. Using soil survey data for qualitative land evaluation. Adv. Soil Sci. 9. 177-213.

Bouma, J., Jongerius, A. \& SCHOOnDERBeek, D., 1979. Calculation of saturated hydraulic conductivity of some pedal clay soils using micromorphometric data. Soil Sci. Soc. Am. J. 43. 261-264.

BOUMA, J. \& VAN LANEN, H. A. J., 1987. Transfer functions and threshold values: from soil characteristics to land value. In: Proc of the Int. Workshop on Quantified Land Evaluation Procedures, 27/04-2/05/1986, Washington, D.C. 106-110. ITC Publication 6. Enschede, The Netherlands.

BuZÁs, I. (ed.), 1993. Methods of Soil Analysis. Part 1-2. (In Hungarian) INDA. Budapest.

CosBY, B. J. et al., 1984. A statistical exploration of the relationships of soil moisture characteristics to the physical properties of soils. Water Resour. Res. 20. 682-690. 
Cresswell, H., McKenzie, N. \& Paydar, Z., 1999. Strategy for determining hydraulic properties of Australian soils using direct measurements and pedotransfer functions. In: Proc. Int. Workshop Characterization and Measurement of the Hydraulic Properties of Unsaturated Porous Media. (Eds.: VAn Genuchten, M. Th. LeIJ, F. \& WU, L.) 1143-1160. University of California. Riverside, CA.

GUPTA, S. C. \& LARSON, W. E., 1979. Estimating soil water retention characteristics from particle size distribution, organic matter content, and bulk density. Water Resour. Res. 15. 1633-1635.

Hodnett, M. G. \& Tomasella, J., 2002. Marked differences between van Genuchten soil water retention parameters for temperate and tropical soils: a new water retention pedotransfer functions developed for tropical soils. Geoderma. 108. 155-180.

KÄTtERER, T., ANDRÉN, O. \& JANSSON, P. E., 2005. Pedotransfer functions for estimating plant available water and bulk density in Swedish agricultural soils. Acta Agric. Scand. Sec. B. 56. 263-276.

LEIJ, F. J. et al., 1999. The UNSODA unsaturated soil hydraulic database. In: Proc. Int. Workshop Characterization and Measurement of the Hydraulic Properties of Unsaturated Porous Media. (Eds.: VAN Genuchten, M. TH. LeiJ, F. \& WU, L.) 1269-1281. University of California. Riverside, CA.

MAKÓ, A. et al., 2005. Estimating soil water retention characteristics from the soil taxonomic classification and mapping informations: consideration of humus categories. Cereal Res. Commun. 33. 113-116.

McKeague, J. A., WANG, C. \& TopP, G. C., 1982. Estimating saturated hydraulic conductivity from soil morphology. Soil Sci. Soc. Am. J. 46. 1239-1244.

Minasny, B. \& McBratney, A. B., 2002. The neuro-m method for fitting neural network parametric pedotransfer functions. Soil Sci. Soc. Am. J. 66. 352-361.

NeMES, A., 2002. Unsaturated Soil Hydraulic Database of Hungary: HUNSODA. Agrokémia és Talajtan. 51. 17-26.

Nemes, A., SchaAp, M. G. \& Wösten, J. H. M., 2003. Functional evaluation of pedotransfer functions derived from different scales of data collection. Soil Sci. Soc. Am. J. 67. 1093-1102.

PACHEPSKY, YA., RAWLS, W. J. \& LIN, H. S., 2006. Hydropedology and pedotransfer functions. Geoderma. 131. 308-316.

PAChePsky, YA., Timlin, D. \& RAWLS, W. J., 2001. Soil water retention as related to topographic variables. Soil Sci. Soc. Am. J. 65. 1787-1795.

PACHEPSKY, YA., TIMLin, D. \& VÁRAllyay, GY., 1995. Artificial neural networks to estimate soil water retention from easily measurable data. Soil Sci. Soc. Am. J. 60. 727-733.

RAJKAI, K., 1988. The relationship between water retention and different soil properties. (In Hungarian) Agrokémia és Talajtan. 36-37. 15-30.

RAJKAI, K., KABOS, S. \& JANSSON, P. E., 1999. Improving prediction accuracy of soil water retention with concomitant variable. In: Proc. Int. Workshop Characterization and Measurement of the Hydraulic Properties of Unsaturated Porous Media. (Eds.: VAN GENUCHTEN, M. TH., LeIJ, F. J. \& WU, L.) 999-1004. USDA. University of California. Riverside.

RajkaI, K., Kabos, S. \& VAN Genuchten, M. TH., 2004. Estimating the water retention curve from soil properties: comparison of linear, nonlinear and concomitant variable methods. Soil and Tillage Res. 79. 145-152. 
RAJKAI, K. \& VÁRALLYAY, GY., 1989. Estimative calculation of hydrophysical parameters from simply measurable soil properties. Agrokémia és Talajtan. 38. 634-640.

RAJKAI, K. et al., 1996. Estimation of water-retention characteristics from the bulk density and particle-size distribution of Swedish soils. Soil Sci. 161. 832-845.

RAWLS, W. J. \& PACHEPSKY, YA., 2002. Using field topographic descriptors to estimate soil water retention. Soil Sci. 167. 423-435.

Romano, N. \& Palladino, M., 2002. Prediction of soil water retention using soil physical data and terrain attributes. J. Hydrology. 265. 56-75.

SchaAp, M. G., LeiJ, F. L. \& VAn Genuchten, M. TH., 1998. Neural network analysis for hierarchical prediction of soil hydraulic properties. Soil Sci. Soc. Am. J. 62. $847-855$.

SPSS for Windows, Rel. 11.0.1. 2001. SPSS Inc. Chicago.

Tempel, P., BAtJes, N. H. \& VAN Engelen, V. W. P., 1996. IGBP-DIS soil data set for pedotransfer function development. Working paper and Preprint 96/05, International Soil Reference and Information Centre (ISRIC). Wageningen.

TÓтH, B. et al., 2006. Use of soil water retention capacity and hydraulic conductivity estimation in the preparation of soil water management maps. Agrokémia és Talajtan. 55. 49-58.

Tóth, G., Hermann, T. \& MÁté, F., 2008. Notes on the information stored in the lower levels of the Hungarian soil taxonomy. Journal of Central European Agriculture. 9. 589-598.

VAN GENUCHTEN, M. TH. \& LEIJ, F. J., 1992. On estimating the hydraulic properties of unsaturated soils. In: Indirect Methods for Estimating the Hydraulic Properties of Unsaturated Soils. (Eds.: VAN GenuChten, M. TH., LeIJ, F. J. \& LUND, L. J.) 114. University of California. Riverside, CA.

VÁRALLYAY, GY. et al., 2009. The state of Hungarian soils (on the basis of the data of the Soil Conservation Information and Monitoring System (TIM)) (In Hungarian). Földművelésügyi Minisztérium Agrárkörnyezetvédelmi Főosztály. Budapest.

VEREECKEN, H. et al., 1989. Estimating the soil moisture retention from characteristic texture, bulk density and carbon content. Soil Sci. 148. 389-403.

Wösten, J. H. M., PAChePsky, YA. A. \& RAWLS, W. J., 2001. Pedotransfer functions: bridging the gap between available basic soil data and missing soil hydraulic characteristics. Journal of Hydrology. 251. 123-150.

WÖsten, J. H. M. et al., 1999. Development and use of a database of hydraulic properties of European soils. Geoderma. 90. 169-185. 